\title{
Autism and nutrition: the role of the gut-brain axis
}

\author{
Marijke M. H. van De Sande, Vincent J. van Buul and Fred J. P. H. Brouns* \\ Maastricht University, Nutrition, Toxicology and Metabolism Research Institute (NUTRIM), Faculty of Health, \\ Medicine and Life Sciences (FHML), Department of Human Biology, PO Box 616, 6200 MD, Maastricht, The Netherlands
}

\section{Abstract}

Autism spectrum disorder (ASD) is characterised by deficits in the ability to socialise, communicate and use imagination, and displays of stereotypical behaviour. It is widely accepted that ASD involves a disorder in brain development. However, the real causes of the neurodevelopmental disorders associated with ASD are not clear. In this respect, it has been found that a majority of children with ASD display gastrointestinal symptoms, and an increased intestinal permeability. Moreover, large differences in microbiotic composition between ASD patients and controls have been reported. Therefore, nutrition-related factors have been hypothesised to play a causal role in the aetiology of ASD and its symptoms. Through a review of the literature, it was found that abnormalities in carbohydrate digestion and absorption could explain some of the gastrointestinal problems observed in a subset of ASD patients, although their role in the neurological and behavioural problems remains uncertain. In addition, the relationship between an improved gut health and a reduction of symptoms in some patients was evaluated. Recent trials involving gluten-free diets, casein-free diets, and pre- and probiotic, and multivitamin supplementation show contradictive but promising results. It can be concluded that nutrition and other environmental influences might trigger an unstable base of genetic predisposition, which may lead to the development of autism, at least in a subset of ASD patients. Clear directions for further research to improve diagnosis and treatment for the different subsets of the disorder are provided.

Key words: Autism spectrum disorder: Treatment: Diagnosis: Gluten-free diets: Gut-brain axis

\section{Introduction}

Autism spectrum disorder (ASD) is a syndrome with various subgroups, boundaries and treatments ${ }^{(1)}$. Symptoms include a reduced ability to socialise, to communicate and to use imagination, and displays of stereotypical behaviour $^{(2)}$. The Diagnostic and Statistical Manual of Mental Disorders, fourth edition (DSM-IV) handbook lists five subtypes of ASD: autistic disorder; Asperger's disorder; childhood disintegrative disorder; pervasive developmental disorder not otherwise specified; and Rett's disorder.

Currently, no diagnostically relevant biological tests for ASD exist. Therefore, diagnoses are based on observed deficits in reciprocal social interaction and communication ${ }^{(3)}$. Among the children diagnosed with autism between 6 and 17 years old, the amount of co-morbidities, such as attention-deficit disorder, attention-deficit/hyperactivity disorder, anxiety problems and behavioural problems are reported as high as $87.3 \%{ }^{(4)}$. The prevalence of autism is currently estimated to lie between 45 and 110 per 10000 individuals in the USA. A recently reported increase ${ }^{(5)}$ has been ascribed to increased recognition, changed diagnostic criteria and changing public attitudes towards autism. However, a causal increase by environmental risk cannot be ruled out ${ }^{(6)}$. Common postulated risk factors for autism include high maternal and paternal age, a low level of parental education, a child of male sex, autism in the family, low birth weight or gestational age, and prenatal virus and drug exposures (for example, rubella infection $^{(7)}$, thalidomide ${ }^{(8)}$ and maternal smoking $\left.{ }^{(9)}\right)$.

There is scientific consensus that autism involves a disorder in brain function and development ${ }^{(10-13)}$. The cause of this disorder, however, is not clear. Although several genetic factors are known to influence the aetiology of different types of autism ${ }^{(14)}$, these only apply to a minor part of the autistic population ${ }^{(15,16)}$. Moreover, several hypotheses point to environmental influences as possibly being causative to autism, including involvement of abnormal gastrointestinal (GI) microbiota composition, autoimmunity, early environmental exposures to viruses and drug compounds ${ }^{(17)}$.

Abbreviations: ASD, autism spectrum disorder; BCM, $\beta$-casomorphin; GI, gastrointestinal; IAG, indolyl-3-acryloylglycine; LNH, lymphoid-nodular hyperplasia; NFA, non-IgE-mediated food allergy.

*Corresponding author: Professor Fred Brouns, email fred.brouns@maastrichtuniversity.nl 
The ambiguity in causation has resulted in a wide variety of proposed treatments ${ }^{(18)}$. With this, autistic patients are currently subjected to numerous 'alternative interventions' by caregivers and researchers ${ }^{(19,20)}$. Some of these are specifically aimed at the diet and improving gut health. Described interventions include gluten- and casein-free diets $^{(19,21)}$, supplementation with pre- and probiotics ${ }^{(22)}$ and supplementation with multivitamins ${ }^{(23-25)}$.

In the present review, we evaluate the current theories and hypotheses concerning the aetiology of autism, with a special focus on the gut-brain axis. On this axis, the mechanisms and interactions of sensory cues and biochemical signals that take place between food, the GI tract and the nervous system can best be described. Through this approach, we discuss the possible alternative nutritional interventions and their efficacy on reducing symptoms of ASD.

\section{Discussion}

To place the nutritional interventions in context, it is important to study the causation of disorders in brain function and development before developing symptoms related to the different subcategories of ASD. For the purpose of the review, available studies related to the gut-brain axis are described.

\section{Gastrointestinal abnormalities}

GI abnormalities in the gut of autistic children compared with healthy or sibling controls have been studied in multiple trials ${ }^{(22,26-36)}$. In this respect, studies by ValenciMcDermott et $a l^{(37)}$ and Adams et $a l^{(29)}$ have indicated that $70 \%$ of children with ASD report having a history of GI complaints, against $28 \%$ of neurotypical controls, and that GI symptoms are strongly correlated with the severity of autism ( $r 0.59 ; P<0.001)$. The GI abnormalities found in autistic children include malabsorption ${ }^{(38)}$, maldigestion $^{(39,40)}$, microbial overgrowth (fungal, bacterial and viral $^{(31)}$ and abnormal intestinal permeability ${ }^{(28,41)}$. These events could cause symptoms including diarrhoea, constipation, gas, belching, probing and visibly undigested foods ${ }^{(42)}$.

In the study of Wakefield et al. ${ }^{(43)}$, twelve children with regressive autism and GI abnormalities were examined. Of these children, ten displayed lymphoid-nodular hyperplasia (LNH) and eight also displayed abnormalities in the mucosa (including granularity, loss of vascular pattern, and patchy erythema). There were no neurological abnormalities detected in the children.

In $2004^{(44)}$, the same research group conducted a comparable study among 148 children with ASD as well as GI symptoms and thirty developmentally normal controls by ileo-colonoscopy. LNH was found in the ileum of $90 \%$ of autistic children $v .30 \%$ of controls and in the colon of $59 v .23 \%$ of autistic children and controls, respectively.
The presence and severity of ileal LNH was not influenced by diet or age at colonoscopy.

Another study ${ }^{(27)}$ examined thirty-six children with autism and abnormal gastroenterological symptoms. In this study, reflux oesophagitis in twenty-five of the children, chronic gastritis in fifteen, and chronic duodenitis in twenty-four were observed. Likewise, twenty-one children showed low activity of carbohydrate digestive enzymes in the intestine, and twenty-seven showed increased exocrine secretion of pancreatic-bilary fluid after intravenous administration of the GI hormone secretin (the peptide hormone secretin, released by endocrine cells within the duodenal mucosa, promotes sodium bicarbonate and water secretion by the pancreas ${ }^{(36)}$ ).

However, in a study of Black et al. ${ }^{(33)}$, it was found that ninety-six children, that at a later stage were diagnosed as 'autistic or 'possibly autistic', did not suffer more from GI inflammation, coeliac disease, food intolerance or recurrent GI symptoms than the 449 controls without subsequent development of autism. In a recent study ${ }^{(34)}$, including 124 children with autism and two matched controls per case, the lifetime incidence of GI symptoms was found to be 77.2 and $72.2 \%$, respectively. Concentrating on the five formed categories of GI symptoms (constipation; diarrhoea; abdominal bloating, discomfort or irritability; gastro-oesophageal reflux/vomiting; and feeding issues or food selectivity), the autistic children did experience significant higher rates of constipation and 'feeding/food selectivity issues' (specified feeding problems, lactose intolerance, loss of appetite or loss of weight) than did controls. It is suggested, however, that these two categories are primarily influenced by behavioural rather than biological influences ${ }^{(34)}$.

\section{Microbiotic compositions: clostridia and vancomycin}

Bolte $^{(45)}$ hypothesised that abnormal gut microbiota may be involved in the aetiology of ASD patients. Finegold et al. found that children diagnosed with late-onset autism differed from non-autistic controls in microbiotic compositions of faecal flora, gastric and small-bowel samples ${ }^{(32)}$. The authors state that there are several reasons to consider that micro-organisms may be involved in lateonset autism. First, onset of the disease often follows antimicrobial therapy, for example, to treat ear infections that often are present in high frequency and persistency among young ASD patients ${ }^{(46-48)}$. Second, GI symptoms are common at the onset of ASD and often persist. Finally, other antimicrobials may lead to a clear-cut response and relapse may occur when the antimicrobial is discontinued, which is demonstrated with, for example, the antimicrobials vancomycin ${ }^{(49)}$ and metronidazole ${ }^{(50)}$. However, in higher doses, over a longer period of time $(>6 \mathrm{~d}$ of treatment), vancomycin disrupts the anaerobic intestinal microflora and promotes colonisation by pathogens ${ }^{(51)}$.

Indeed, significantly more clostridia and ruminococci were found in the stools of the autistic group (geometric 
mean count of $2 \cdot 1 \times 10^{6}$ colony-forming units) $v$. the control group $\left(1.6 \times 10^{5}\right.$ colony-forming units) using $16 \mathrm{~S}$ ribosomal RNA gene sequencing. Non-spore-forming anaerobic and micro-aerophilic bacteria were found in four of five children with autism, whereas none of the control children showed these bacteria. Furthermore, both the gastric and small-bowel specimens from children with autism were more likely to have (a higher number of species of) clostridia than was true for the controls. Song et $a{ }^{(26)}$ found significantly higher mean cell counts of Clostridium cluster groups I and XI and Clostridium boltae in fifteen autistic children compared with eight controls using real-time PCR. Parracho et al. ${ }^{(22)}$ used fluorescence in situ hybridisation, and reported higher levels of C. bistolyticum in fifty-two autistic children compared with both healthy unrelated children and healthy siblings $(P<0.01$ and $P<0.05$, respectively). However, no relationship was evident between the levels of any of the bacterial populations examined and age, sex, antibiotic history or diet type. GI problems were associated with high levels of clostridia $(P<0.001)$ in patients with ASD, but this is apparent, as $91.4 \%$ of the autistic group and none of the unrelated control group had GI symptoms ${ }^{(22)}$. Martirosian et $a l{ }^{(52)}$ detected higher levels of $C$. perfringens, but equal amounts of Clostridium spp. in forty-one autistic children compared with ten non-autistic controls using anaerobic bacterial cultivation.

Concluding from the findings listed above, it was hypothesised that: (1) relapse in autistic children after discontinuation of antibiotic treatment is due to the presence of Clostridium spores which then germinate to reproduce the disease; (2) the increased incidence of autism is related to the widespread exposure to Clostridium spores in the environment; and (3) the increase in families with multiple cases of autism is also due to contact with spores. However, the studies conducted so far are of low to moderate quality, predominantly due to small sample sizes and inadequate or absent explanation of sources of the sample, timing of the study and potential biases (for an extensive review, see also Cao et al. $\left.{ }^{(53)}\right)$. In addition, the studies used a wide range of different assessment methods, which makes it impossible to make qualitative comparisons. Clearly, carefully designed studies are warranted to verify any cause-effect relationships.

\section{Indolylacryloylglycine}

Another aspect in the relationship between micriobiota and (late-onset) ASD involves urinary indolyl-3-acryloylglycine (IAG). IAG is a regular constituent of human urine and is produced by gut microflora ${ }^{(54,55)}$. It has been speculated that high levels of IAG in urine are an indication of gut dysbiosis $^{(56)}$. A few studies found increased levels of IAG in autistic individuals compared with asymptomatic controls ${ }^{(54,55)}$.

Normally, tryptophan is catabolised to indole pyruvate and indole acetate and can be detected in the urine of normal subjects ${ }^{(57)}$. The formation of IAG is possibly the result of another less-investigated pathway. It is likely that intestinal micro-organisms catabolise tryptophan to indole derivatives which are then absorbed and converted to indolylacrylic acid (IAcrA) and after conjugation of IAcrA with glycine in the liver IAG is formed ${ }^{(58)}$. Shattock et al. ${ }^{(59)}$ hypothesised that IAG represents the detoxified version of a acidic precursor that affects membranes throughout the body, particularly those lining the gut wall and the blood-brain barrier, making them permeable to other biologically active products such as peptides. This would occur either by replacing the (flat) long-chain fatty acids that make up the lipid elements of the membrane, or by inserting itself between these layers ${ }^{(60)}$. However, very little evidence exists to support this suggestion. To the best of our knowledge, only one publication showed that the levels of highly unsaturated fatty acids in erythrocyte membranes are affected by the presence of IAcrA ${ }^{(61)}$.

\section{Abnormal intestinal permeability}

Two studies ${ }^{(28,41)}$ found an abnormally high intestinal permeability in autistic children, compared with normal controls. D'Eufemia et al. ${ }^{(41)}$ included twenty-one autistic and forty healthy age-matched children, both groups without clinical evidence of any GI disease or allergy. The results highlighted some damage to tight junctions of the gut mucosa, and showed that in some patients with infantile autism damage to these junctions occurs in the absence of established GI disorders. Recent results from a study by de Magistris et al. ${ }^{(28)}$ replicated the finding of an abnormal intestinal permeability in $36.7 \%$ of ninety autistic children, as well as in $21.2 \%$ of their 146 siblings. This was significantly higher than in the 146 healthy controls (4.8\%). They also found GI symptoms in $46.7 \%$ of the autistic children, although these symptoms were not related to the intestinal permeability. Furthermore, ASD patients on a reported gluten-free, casein-free (GFCF) diet had significantly lower intestinal permeability values compared with those on an unrestricted diet and controls. Specific causes were not described, although the authors suggest the existence of a genetic GI factor that is involved in the pathology of a subgroup of $\mathrm{ASD}^{(28)}$.

Previously, intestinal permeability was found to be involved in the aetiopathogenesis of several autoimmune diseases, including Crohn's disease ${ }^{(62)}$, coeliac disease ${ }^{(63)}$ and type 1 diabetes ${ }^{(64)}$. Significantly lower levels of the health-promoting bifidobacteria species and the mucolytic bacterium Akkermansia muciniphila were found in children with autism ${ }^{(65)}$. It is suggested that low levels of bifidobacteria are related to unhealthy (more putrefactive) gut microbiome composition and metabolism. The change in A. muciniphila suggests mucus barrier changes. A. muciniphila is a mucin-degrading bacterium extensively present in the guts of healthy adults, but reduced in patients with Crohn's disease, ulcerative colitis and in 
elderly individuals. A thinner GI mucus barrier could represent less substrate for mucin-degrading bacteria and hence lower numbers in the faeces. Thus, although a degraded mucus barrier and less mucus-degrading bacteria seems paradoxical, A. municiphila could be a possible marker for altered mucus turnover and a thin, thus possibly more 'leaky', gut barrier ${ }^{(66)}$.

However, another recent study showed no abnormal intestinal permeability in autistic children compared with healthy siblings and non-related controls ${ }^{(67)}$. The same test (a differential sugar-absorption test) was used as well as measuring glucagon-like peptide-2, an enteroendocrine molecule that is released from the GI tract in response to nutrients, which has been found to reduce intestinal permeability ${ }^{(68,69)}$. No differences were observed in the fourteen ASD patients compared with eight siblings and seven non-related controls. However, the small size of this pilot study may not have been sufficient to show a statistically significant difference between the two groups. Therefore, further research is warranted to establish whether there is a true higher incidence of enhanced intestinal permeability in ASD.

\section{Metabolic abnormalities}

Several metabolic abnormalities have been found in autistic children. These include, amongst others, defects in methylation, oxidative stress ${ }^{(70,71)}$, and disturbed concentration of amino acids in plasma ${ }^{(72)}$. Also, abnormal sulfur metabolism ${ }^{(72-74)}$, lower concentrations of mammalian-microbial co-metabolites and a more active nicotinic acid metabolism $^{(75)}$, have been found in autistic individuals. Below, we will review this in more detail.

\section{Methylation, sulfation and oxidative stress}

Several studies have reported lower baseline plasma concentrations of methionine, $S$-adenosylmethionine, homocysteine, cystathionine, cysteine, and total glutathione and significantly higher concentrations of $S$-adenosylhomocysteine, adenosine and oxidised glutathione in autistic children ${ }^{(70,71)}$. These findings implicate impaired methylation and oxidative stress in autistic individuals. Geier et al. ${ }^{(73)}$ found that patients with ASD show decreased trans-sulfuration metabolites and reduced sulfate concentrations. The same group of researchers ${ }^{(76)}$ found significantly decreased plasma reduced glutathione, cysteine, taurine, sulfate, and increased oxidised glutathione in the plasma of autistic children relative to agematched neurotypical controls. Other research also found a decreased ability to form sulfated metabolites ${ }^{(77)}$ and lower plasma sulfation products ${ }^{(78)}$ in autistic individuals. The inability of autistic individuals to properly respond to toxins may be partially due to an undersupply of sulfate substrate for the sulfotransferases, which results in impaired sulfur-dependent detoxification pathways. Sulfate substrate is presumably produced by the sulfoxidation of cysteine $^{(79)}$, which was found to be decreased ${ }^{(73)}$.

Geier et $a l .{ }^{(73)}$ concluded that the abnormal (oxidised) glutathione levels result in a disturbance of the reduced/ oxidised glutathione redox equilibrium. This may subsequently affect processes in which this equilibrium is involved, such as nitrogen and oxygen free radical scavengers, protein redox status and enzyme activity, cell membrane integrity, signal transduction and gene expression. Furthermore, increased levels of oxidised glutathione in plasma were found to be correlated with increased levels of Hg-associated urinary porphyrins. Geier et al. ${ }^{(73)}$ suggested that increased levels of oxidised glutathione may contribute to abnormal trans-sulfuration and consistently result, in co-occurrence with low glutathione levels and increased oxidative stress, in a higher risk of infections and inflammation in autistic children ${ }^{(73)}$.

These systemic impairments of sulfation in ASD patients could theoretically threaten the stability of the catecholamine transmitter systems, the integrity of the gut lining, and heighten vulnerability to food-borne or pollutant xenobiotic overload to tissues ${ }^{(77)}$.

\section{Glutamate, glutamine and other amino acids}

An altered urinary amino acid excretion has been frequently found in autistic children compared with agematched controls ${ }^{(80)}$. In children with ASD, Pangborn \& Baker $^{(81)}$ found very low levels of some amino acids on urinalysis, such as taurine (in $62 \%$ of subjects), lysine (in $59 \%$ ), phenylalanine (in $54 \%$ ) and methionine (in $51 \%)$. The researchers also found, to a lesser extent, below-normal levels of tyrosine, leucine, glutamine, valine and asparagine ${ }^{(81)}$. In the plasma of autistic children $^{(82)}$, however, increased levels of glutamic acid, phenylalanine, asparagine, tyrosine, alanine and lysine were found. The parents and siblings of these patients had these increased plasma levels as well, compared with non-autistic and non-related controls. The authors suggest that this may reflect a reduced capacity to remove amino acids from the system, or, without supplying evidence, a relative permeable blood-brain barrier. An altered plasma level of amino acids could be related to nutritional intake, but the sampling was done at home, thus under different (nutritional) conditions between the families. Raised plasma levels of phenylalanine and tyrosine levels may theoretically lead to higher concentrations of catecholamines such as dopamine and noradrenaline ${ }^{(82)}$. It is hypothesised that elevated dopaminergic $^{(83)}$ and (nor)adrenergic ${ }^{(84)}$ functions could be involved in the development of autism. However, the existing research does not provide strong support for these mechanisms due to inconsistent results and lack of methodological quality ${ }^{(83)}$.

Also, the balance between glutamic acid and glutamine, in plasma, was found to be different in ASD patients ${ }^{(85)}$ and 
their parents ${ }^{(82)}$ compared with controls. Glutamic acid is an excitatory neurotransmitter crucial to neuronal plasticity and the maintenance of cognitive functioning ${ }^{(85)}$, which is normally removed from the synapse after a receptor has been activated and is carried by transporter proteins to astrocytes $^{(86)}$. Here, it is stored as glutamine via glutamine synthetase, and later transported back to the presynaptic neurons and reconverted to glutamate, via glutaminase. Glutamine is required for the metabolism of enterocytes, and lower levels may thus have a deleterious effect on gut function, or a disturbed microbiota composition ${ }^{(82)}$. Glutamine synthase, which converts glutamate into glutamine ${ }^{(87)}$, is down-regulated by activated astrocytes. Glutaminase, which converts glutamine into glutamate ${ }^{(88)}$, is activated by necrotic neurons in microglia. Activated astrocytes and necrotic neurons in microglia characterise gliosis, which is found to be increased in autistic brains ${ }^{(89)}$.

Thus far, most observations made have led to speculations about possible metabolic disturbances. However, it is also suggested that amino acid deficiencies found in children with autism are due to poor protein nutrition and food selectivity ${ }^{(90)}$. ASD children who were on restricted diets had an increased prevalence of essential amino acid deficiencies and lower plasma levels of essential acids, including tyrosine and tryptophan, than both controls and ASD children on unrestricted diets ${ }^{(91)}$. Thus, findings of abnormal levels of several amino acids might be attributable to poor nutrition secondary to food selectivity $^{(91)}$, instead of actual metabolic abnormalities. However, the multiple findings indicating metabolic difficulties suggest that food selectivity may not be the only cause of changed amino acid levels in autistic children.

\section{Carbohydrate digestion and absorption}

Intestinal bacteria encode the enzymes glycoside hydrolase and polysaccharide lyase, which are absent in humans, necessary for the fermentation of poly- and oligosaccharides. These bacteria produce SCFA as endproducts of polysaccharide fermentation. These SCFA serve as energy substrates for colonocytes, modulate colonic $\mathrm{pH}$, regulate colonic cell proliferation and differentiation, and contribute to hepatic gluconeogenesis and cholesterol synthesis ${ }^{(92,93)}$.

Recently, intestinal biopsies (ileum) from children with autism and GI problems showed a deficiency of ileal transcripts encoding disaccharidases and hexose transporters, indicative of impairment of the primary pathway for carbohydrate digestion and transport in enterocytes. Since the conditions that impact on transcription are not specific for a specific segment but rather for the whole absorptive intestine, it is reasonable to assume that similar effects will also be present in the duodenum and jejunum. Indeed, one other study ${ }^{(27)}$ reported low enzyme activities in $58 \%$ of children with ASD in the duodenum. Reduced carbohydrate digestion and absorption can lead to accumulation of saccharides in the intestinal lumen, resulting in osmotic diarrhoea, bloating and flatulence ${ }^{(94)}$ The expression levels of disaccharidases and hexose transporters may be controlled, in part, by the transcription factor CDX2 (caudal type homeobox 2). In autistic children with GI symptoms, $86.7 \%$ had CDX2 levels below the 50 th percentile of control children with GI symptoms. Moreover, $46.7 \%$ of autistic children with GI symptoms had at least a two-fold decrease in mean CDX2 expression relative to the control children with GI symptoms ${ }^{(94)}$. In addition, an altered gut microbiota was observed, including increased levels of caecal Firmicutes, especially clostridia, and a higher caecal Firmicutes:Bacteroidetes ratio $^{(94)}$. This dysbiosis of the mucoepithelium was associated with the deficiencies in host disaccharidase and hexose transporter messenger RNA expression.

In conclusion, abnormalities in carbohydrate digestion and absorption could possibly explain some of the GI problems observed in a subset of ASD patients, although their role in the neurological and behavioural problems remains uncertain.

\section{Intestinal inflammation}

Chronic inflammation in the gut can damage the epithelial cell layer ${ }^{(95)}$. When present, this may explain the increased intestinal permeability found in ASD patients. In this respect, intestinal biopsies among fifty-two regressive autistic children revealed significantly increased $\mathrm{CD}^{+}$ and $\mathrm{CD}^{+} \mathrm{CD}^{+}$in the epithelium as well as $\mathrm{CD}^{+}$in the lamina propria compared with developmentally normal non-inflamed control groups, reaching levels similar to inflamed controls ${ }^{(96)}$. Up-regulation of pro-inflammatory cytokines in the intestinal mucosa of autistic children with GI symptoms has also been reported ${ }^{(97,98)}$. Additionally, increasing cytokine levels were associated with more impaired communication and aberrant behaviours ${ }^{(98)}$. However, in another study ${ }^{(99)}$, pro-inflammatory cytokines IL-6, IL- 8 and IL-1 $\beta$ were not found to be elevated in the mucosa. In addition, two independent markers of inflammatory reactions in the gut, i.e. rectal NO and faecal calprotectin, were measured in twenty-four children with autism. As in only two of the children the level of one of these markers was increased, the investigators were unable to disclose evidence of a link between the autistic disorder and active intestinal inflammation ${ }^{(100)}$. Thus, controversial results exist regarding a causal role of GI inflammation in the aetiology and/or behavioural aspects of autism.

\section{Food allergies}

In food allergy, presentation of food antigen leads to a response by $\mathrm{T}$ cells and subsequently to an initiation of a food-mediated immune response ${ }^{(101)}$. Parental reports have shown a significantly greater incidence of food allergy in ASD patients compared with healthy 
controls $^{(102)}$. Lucarelli et al. ${ }^{(103)}$ found in 1995 that an oral challenge with cows' milk protein led to worsening of some of the behavioural symptoms of autistic children, and that these children express significantly higher serum levels of IgA, IgG and IgM for casein and IgA for lactalbumin and $\beta$-lactoglobulin compared with healthy controls. Recently, Sabra et al. ${ }^{(104)}$ hypothesised that food allergy is the pivotal causative factor that produces lesions in the ileum that consist of enlarged lymphoid nodules containing large collections of lymphocytes in the GI lymphoid tissues adjacent to Peyer's patches. These GI lesions would allow the entry of food antigens across the inflamed mucosa of the bowel and elicit an inflammatory response in the GI tract ${ }^{(104)}$. They found $\mathrm{LNH}$, reactive lymphoid follicular hyperplasia and chronic inflammation in twelve children with attention-deficit/hyperactivity disorder, autism, anorexia and/or migraine. Th1-associated cytokines were found to be decreased compared with control values, which, together with a predominance of $\mathrm{CD}^{+}$cells, support an immunological basis for non-IgEmediated food allergy (NFA) in this group ${ }^{(104)}$.

Another research group ${ }^{(105)}$ also supports the hypothesis of an existence of NFA in autistic children. They found more TNF- $\alpha$ and IL-12 in peripheral blood mononuclear cells of children with autism than controls, when stimulated with cows' milk protein, $\beta$-lactoglobulin and $\alpha$-lactoalbumin, irrespective of objective GI symptoms ${ }^{(106)}$. However, NFA may play a lesser role in GI symptoms in older children with autism, as most children probably outgrow NFA during the first 2 years of life with maturation of the gut immune system and the establishment of oral tolerance ${ }^{(107)}$. Concluding, NFA could partially explain GI symptoms and the suggested benefits of dietary interventions such as the GFCF diet in some autistic children under the age of 2 years.

\section{Nutritional interventions}

As introduced, some treatment strategies of autism are specifically aimed at dietary measures to improve gut health. The most important are described below.

\section{Gluten- and milk protein-free diets}

A regularly proposed treatment to reduce food-related effects in autism is a GFCF diet. Many non-peer-reviewed articles, books ${ }^{(108)}$ and websites support and encourage the application of this diet. Previous research among 284 autistic children indicates that approximately $15.5 \%$ of autistic children in the USA use this diet as a complementary treatment ${ }^{(109)}$. Consequently, there have been many reports on the role of a GFCF diet on alleviating several symptoms of autistic individuals ${ }^{(19,110-116)}$ (however, not all of sufficient methodological quality; see below). Significant improvements have been noted within psychological and behavioural categories in vocal and non-vocal communication, attention and concentration, episodes of aggressiveness, affection, motor skills, sleeping patterns, displaying of routines and rituals, anxiety, empathy and responses to learning ${ }^{(19,111,112,115,116)}$. Moreover, reintroduction of dietary gluten elicited a worsening of behaviours in areas of hyperactivity and impulsivity, stereotyped behaviours, aggression and language and communication skills ${ }^{(19)}$. A slight initial worsening in behaviour after introduction of the GFCF diet was also noted, which was suggested to be comparable with the withdrawal behaviours exhibited by opioid addicts on the removal of opioids ${ }^{(19)}$. Changes in physical and physiological areas were measured in some studies as well. One patient showed abnormal peptides not found in controls, including $\beta$-casomorphin (BCM), $\alpha$-gliadin, dermorphin, deltorphin I and II, and morphine-modulating neuropeptide ${ }^{(117)}$. Some of these have also been observed in other studies ${ }^{(57,112,118)}$.

Nevertheless, when critically reviewing these studies it appears that most of these lack sufficient methodological quality ${ }^{(119,120)}$, and a short overview of the trials that have been conducted, to our knowledge, is shown in Table 1.

All the studies except for one lack a control group, and therefore have a high placebo response rate, due to high levels of parental and/or clinician expectancy, a presumed lack of side effects and the degree of parental effort and resources that are invested in the treatment. The outcomes of the three studies with the highest experimental validity are negative, and showed no statistically significant difference between the control and intervention groups after implementing the GFCF diet ${ }^{(110,113,114)}$. Also, other studies showed no changes in urinary peptide levels of gluten, casein and $\mathrm{IAG}^{(22,121)}$. Moreover, exclusion of casein from the diet was found to decrease intake of dairy foods as well as micronutrients associated with dairy foods. Although supplementation improved many of the inadequacies seen in autistic children on a GFCF diet, nutrients important for bone health such as $\mathrm{Ca}$ and $\mathrm{P}$ were still inadequate $^{(122)}$.

The introduction of the GFCF diet is derived from the opioid excess theory of autism. Opioids are chemical substances that have a morphine-like activity in the body, and act by binding to opioid $\mu$-, $\delta$ - and $\kappa$-receptors. These receptors are located principally in the central nervous system as well as the GI tract and activation elicits adenylatecyclase inhibition, $\mathrm{K}^{+}$channel activation, or $\mathrm{Ca}^{2+}$ inactivation $^{(123)}$. The opioid excess theory states that children with autism are symptomatic due to excess of peptides, derived endogenously, as well as exogenously from incomplete breakdown of certain foods, both possibly due to peptidase deficiencies. In particular, gluten-derived peptides from wheat and some other cereals and casein from milk and dairy products are suspected to be involved in autism ${ }^{(19,124,125)}$. Opioid-like molecules include, for example, $\alpha$-gliadin, dermorphin, novel autism peptide I 
Table 1. Studies assessing the effect of gluten and casein related dietary interventions on autism spectrum disorder (ASD) symptoms

\begin{tabular}{|c|c|c|c|c|c|}
\hline Author & Participants & Intervention & $\begin{array}{l}\text { Dependent } \\
\text { variable }\end{array}$ & Outcome & Remarks \\
\hline $\begin{array}{l}\text { Adams \& Conn } \\
\qquad(1997)^{(163)}\end{array}$ & $\begin{array}{l}1 \mathrm{~m}, 1 \mathrm{f}, \text { age } \\
3 \text { years, } \\
\text { autism }\end{array}$ & GFCF diet for 24 months & $\begin{array}{l}\text { Anecdotal parent report of } \\
\text { overall behaviour }\end{array}$ & $\begin{array}{l}\text { Positive; authors report } \\
\text { improvements after } 2 \text { weeks of } \\
\text { intervention, but no quantifiable data } \\
\text { are displayed }\end{array}$ & $\begin{array}{l}\text { No experimental design } \\
\text { Not enough detail to replicate } \\
\text { No operational definitions } \\
\text { No treatment fidelity } \\
\text { No inter-observer agreement } \\
\text { No attempt to control alternative } \\
\text { explanations }\end{array}$ \\
\hline $\begin{array}{l}\text { Bird et al. } \\
\qquad(1977)^{(110)}\end{array}$ & $\begin{array}{l}1 \mathrm{~m} \text {, age } 9 \text { years, } \\
\text { autism }\end{array}$ & GFCF diet for approximately $9 \mathrm{~d}$ & $\begin{array}{l}\text { Direct observation of pica, } \\
\text { inappropriate vocalisa- } \\
\text { tions, cooperation and } \\
\text { motor activity }\end{array}$ & $\begin{array}{l}\text { Neutral; PND }=3 \% \text { (averaged across } \\
\text { dependent variables) }\end{array}$ & $\begin{array}{l}\text { No attempt to control alternative } \\
\text { explanations and diet } \\
\text { Implemented for a brief time }\end{array}$ \\
\hline $\begin{array}{l}\text { Cade et al. } \\
\qquad(2000)^{(112)}\end{array}$ & $\begin{array}{l}28 \mathrm{~m}, 22 \mathrm{f}, \text { age } \\
3.5-16 \text { years, } \\
\text { autism }\end{array}$ & GFCF diet for 12 months & $\begin{array}{l}\text { UPL, blood tests of anti- } \\
\text { bodies to gluten and } \\
\text { casein, parent, } \\
\text { physician, and teacher } \\
\text { ratings of social isolation, } \\
\text { eye contact, speech, } \\
\text { learning skills, } \\
\text { hyperactivity, stereotypical } \\
\text { activity, hygiene, panic } \\
\text { attacks and self-mutilation }\end{array}$ & $\begin{array}{l}\text { Positive; baseline levels of } \\
\text { antibodies and UPL were higher in the } \\
\text { group with autism than in the neurotypical } \\
\text { control group. Significant changes from } \\
\text { baseline on ratings of social isolation, eye } \\
\text { contact, speech, learning skills, hyper- } \\
\text { activity, stereotypical activity, panic } \\
\text { attacks and } \\
\text { self-mutilation }\end{array}$ & $\begin{array}{l}\text { Analysis of antibodies and UPL was } \\
\text { conducted at pre-intervention only } \\
\text { No operational definitions of parent- and } \\
\text { teacher-rated behaviours } \\
\text { No treatment fidelity } \\
\text { No inter-observer agreement } \\
\text { No attempt to control alternative } \\
\text { explanations } \\
\text { Not blinded } \\
\text { No control group }\end{array}$ \\
\hline $\begin{array}{l}\text { Harris \& Card } \\
\qquad(2012)^{(164)}\end{array}$ & $\begin{array}{l}9 \mathrm{~m}, 5 \mathrm{f}, \text { mean } \\
\text { age } 9 \\
\text { (sD 1.9) years, } \\
\text { austism (includ- } \\
\text { ing Asperger's } \\
\text { syndrome) }\end{array}$ & $\begin{array}{l}\text { Seven of thirteen children were } \\
\text { on a GFCF diet as assessed } \\
\text { by FFQ }\end{array}$ & GSRS and CARS & $\begin{array}{l}\text { Neutral; GSRS and CARS scores did not } \\
\text { differ significantly } \\
\text { according to GFCF diet }\end{array}$ & $\begin{array}{l}\text { Small sample size } \\
\text { Subjective nature of the questionnaires } \\
\text { Uncertain ability of parents to accurately } \\
\text { quantify the severity of their children's } \\
\text { symptoms }\end{array}$ \\
\hline
\end{tabular}
$\begin{array}{ccc}\text { Herbert \& Buck- } & 1 \mathrm{f} \text {, followed from } & \text { Multiple interventions including } \\ \text { ley }(2013)^{(165)} & \text { age } 4 \text { to13 } & \text { a GFCF ketogenic 1.5:1 ratio }\end{array}$ years, severe diet (14 months at 12 years)

$\begin{array}{cc}\text { Knivsberg et al. } & 20 \mathrm{~m} \text {, age } 7.5 \\ (2002)^{(115)} & \text { years, }\end{array} \quad$ GFCF diet for 12 months

$\begin{array}{cc}\text { Knivsberg et al. } & 8 \mathrm{~m}, 7 \mathrm{f} \text {, age } \\ (1990, & 6-14 \text { years, } \\ 1995)^{(166,167)} & \text { autism }\end{array}$

Three diets for 48 months used: GF, milk reduced; milk free, gluten reduced; and milk free, GF; number of subjects assigned to each diet not reported
Among others, seizures,

brain activity (measured through an electroencephalogram), weight and

UPL, Leiter Nonverbal Intelligence Test, linguistic abilities using the ITPA and the Reynells språktest, Movement Assessment Battery for Children, parent and teacher behaviour ratings using the DIPAB

UPL, C-Raven, Tajford Observation Scheme, parent and teacher behaviour ratings using the DIPAB
Positive; reported symptoms decreased (although not quantified). Weight loss of 60 pounds $(27 \mathrm{~kg})$ in 1 year. Cholesterol increased slightly

Positive; pre-post test showed improvements in the DIPAB, and statistically significant changes in the other standardised assessments

Positive; decreased bizarre behaviour and isolation, statistically significant improvement on C-Raven and Tafjord scores; and improvement in multiple areas on teacher evaluations. Three subjects who stopped the diet had a reversal of gains made in

C-Raven scores
Case study including multiple

$$
\text { interventions }
$$

Causality remains unproven

Categorising groups according to gains after intervention increased the likelihood of finding statistical significance

No treatment fidelity

No attempt to control alternative explanations

Single blind

No experimental design

Not enough information to replicate No treatment fidelity

No inter-observer agreement

No attempt to control alternative explanations

Results for the different diets not reported separately

No control group 


\begin{tabular}{|c|c|c|}
\hline Author & Participants & Intervention \\
\hline $\begin{array}{l}\text { Lucarelli et al. } \\
\quad(1995)^{(103)}\end{array}$ & $\begin{array}{l}30 \mathrm{~m}, 6 \mathrm{f}, \text { age } \\
8-13 \text { years, } \\
\text { autism }\end{array}$ & $\begin{array}{l}\text { Free of allergens identified for } \\
\text { individual participants and } \\
\text { restriction of cows' milk for } \\
2 \text { months }\end{array}$ \\
\hline
\end{tabular}

2 months
Dependent

\begin{tabular}{|c|c|c|}
\hline $\begin{array}{l}\text { O'Banion et al. } \\
(1987)^{(168)}\end{array}$ & $\begin{array}{l}1 \mathrm{~m} \text {, age } 8 \text { years, } \\
\text { autism }\end{array}$ & $\begin{array}{l}\text { Alternating } 4 \mathrm{~d} \text { periods of fasting } \\
\text { (only water allowed) and } 4 \mathrm{~d} \\
\text { periods in which only one } \\
\text { type of food was allowed } \\
\text { per } d\end{array}$ \\
\hline $\begin{array}{l}\text { Patel \& } \\
\text { Curtis } \\
(2007)^{(111)}\end{array}$ & $\begin{array}{l}9 \mathrm{~m}, 1 \mathrm{f} \text {, age } 5-8 \\
\text { years, five with } \\
\text { autism + } \\
\text { ADHD, and five } \\
\text { with Asperger's } \\
\text { syndrome + } \\
\text { ADHD }\end{array}$ & $\begin{array}{l}\text { Eight components for 3-6 } \\
\text { months: } \\
\text { 1. Avoidance of mites, moisture, } \\
\text { mould, smoke, pesticides and } \\
\text { toxic cosmetics/cleaners } \\
\text { 2. Organic GCFC diet } \\
\text { 3. Oral administration of } \\
\text { berbine, artemisinin, citrus } \\
\text { abstract and walnut hulls } \\
\text { 4. Injections of antigens } \\
\text { 5. Administration of common } \\
\text { multivitamins and cocktail of } \\
\text { over-the-counter herbs, oils } \\
\text { and extracts } \\
\text { 6. Intravenous chelation } \\
\text { 7. Injections up to three times } \\
\text { weekly of vitamin } B_{12} \\
\text { 8. Special education, behaviour } \\
\text { modification, speech } \\
\text { language pathology, occu- } \\
\text { pational therapy and physical } \\
\text { therapy }\end{array}$ \\
\hline $\begin{array}{l}\text { Reichelt et al. } \\
\quad(1990)^{(169)}\end{array}$ & $\begin{array}{l}10 \mathrm{~m}, 5 \mathrm{f} \text {, age } \\
3-17 \text { years, } \\
\text { autism }\end{array}$ & $\begin{array}{l}\text { Prescribed participants specific } \\
\text { diets based on children's UPL } \\
\text { pattern. Diet variations } \\
\text { included: GFCF, gluten- } \\
\text { restricted, casein-free, and } \\
\text { GF, casein-restricted. Each } \\
\text { diet was implemented for } \\
12 \text { months }\end{array}$ \\
\hline
\end{tabular}

variable

BSE, and a battery of Ig

antibody tests

Outcome

Remarks

Mixed; statistically significant reductions in Ig antibody levels, and improvements in by the BSE

Direct observation of challenging behaviour, movement and laughing

Urinary metal concentrations and parent report of behaviour change

Unclear; wheat, maize, tomatoes, sugar, mushrooms and dairy

products were suggested by the authors to be associated with increases in behaviour

Positive; statistically significant $(P<0.001)$ decrease in urinary $\mathrm{Pb}$ concentrations, reported behavioural improvements from parents

\section{UPL, blood tests of antibodies, and behaviour questionnaire}

Positive; statistically significant decrease in UPL and improvements in antibodies and behaviour
Results for are conclusive; however, results regarding behaviour are suggestive due to:

\section{No treatment fidelity}

No inter-observer agreement

No attempt to control alternative explanations

Not blinded

Adaptation of BSE

No control group

No experimental design

Cessation of experiment during key

phase of study

Extremely high likelihood for carry-over effects from extreme food deprivation stress and fear

Confounded data

Pilot study

No experimental design

No treatment fidelity

No inter-observer agreement

Potential behaviour improvement from

components other than diet (for

example, behaviour modification)
No operational definitions

No treatment fidelity

No inter-observer agreement

No attempt to control alternative explanations

Results for the different diets not reported separately

No statistical analysis reported

No control group 
and $\mathrm{III}^{(117)}$ and $\mathrm{BCM}^{(40,126)}$. The resulting peptides may have direct opioid action or may act as ligands to the enzymes that would break down the endogenous opioids ${ }^{(125)}$. A few studies have reported indirect supportive results for this hypothesis, namely an abnormal intestinal permeability in autistic subjects, observed using a differential sugar-absorption test ${ }^{(41,28)}$ and an abnormal (high) peptide content in the urine of autistic children $^{(57,112,117,118,127)}$. Through the immune system, an alternative account of this issue is proposed. It was recently discussed that microglial in the brain can be activated by infection and inflammation, causing behavioural changes ${ }^{(128)}$.

Cows' milk-derived BCM, which is thought to have bioactive properties, is extensively studied for its potential role in several human diseases. It is found in bovine as well as mother's milk ${ }^{(129)}$ and acts as a substrate for dipeptidyl peptidase 4 (DPP-IV), which is a cell-surface protease present on the brush border of the intestine, kidney and liver ${ }^{(130)}$. A defect in DPP-IV, a brush-border peptidase which normally digests dietary opioids ${ }^{(131)}$, could cause the presence of opioid peptides such as BCM in the urine of children with autism ${ }^{(117)}$. In a study by Kost et $a l .{ }^{(132)}$, ninety infants, of which thirty-seven were fed with mother's milk and fifty-three were fed with formula containing cows' milk, were investigated on levels of human and bovine BCM. Elevated basal bovine BCM was found in blood plasma of cows' milk-fed infants who showed delay in psychomotor development and elevated muscle tone. The authors therefore suggested the deterioration of bovine BCM elimination as a risk factor for delay in psychomotor development and autism. However, other studies, reviewed by Hunter et al. ${ }^{(133)}$, could not find defects or abnormalities in DPP-IV in autistic subjects. Lacking direct evidence, however, this theory remains speculative.

\section{Dietary pre- and probiotic supplementation}

The symptoms of inflammatory bowel disease and irritable bowel syndrome are quite similar to those of the GI symptoms in ASD patients, namely abdominal pain or discomfort (which sometimes lessens upon defecation), and are associated with changing stool frequency and/or changing stool consistency ${ }^{(134)}$. Due to these similarities and the established role of probiotics in the treatment of inflammatory bowel disease (see below), a possible treatment of autism with probiotics has been proposed. Since autistic children also frequently suffer from other GI disorders, studies have been undertaken to understand the composition of gut microbiota in autistic children and to modify the gut microbiota and its metabolism favourably when required. In this respect, some bacteria are believed to be harmful through the production of harmful metabolites, and some bacteria are thought to be health-promoting, such as the bifidobacteria and lactobacilli ${ }^{(135)}$. The latter 
are believed to provide protection against infection in the gut and to help in maintaining an efficient barrier function and a healthy immune function ${ }^{(135)}$.

Probiotics are live micro-organisms, which when administered in adequate amounts confer a health benefit on the host ${ }^{(136)}$. They are supposed to give relief from lactose maldigestion ${ }^{(137,138)}$, reducing the related episodes of diarrhoea $^{(139,140)}$. Additionally, probiotics are suggested to help reduce risk factors associated with inflammatory bowel disease $^{(141,142)}$, colorectal cancer ${ }^{(143)}$ and impaired gut-associated immune responses ${ }^{(144-146)}$.

In a double-blind, placebo-controlled study by Parracho et al. ${ }^{(147)}$, Lactobacillus plantarum feeding of children with autism resulted in significant increased levels of the beneficial bacteria lactobacilli and enterococci, and a significant reduction of a cluster of Clostridium, compared with the placebo group. Through a 12 -week study, the probiotic feeding resulted in reduced GI problems and, more importantly, in improved behaviour scores compared with baseline. In this respect, it is noteworthy that, during another double-blind, cross-over study, addressing the effects of the probiotic L. plantarum on autism failed during the changing of treatments in the cross-over period, because parents (who were blinded for the intervention) of children treated with the actual probiotics refused to make the switch, as they wanted their autistic children to continue their improvement ${ }^{(148)}$. Noted improvements were decreased levels of clostridia bacteria in the stools and a positive effect on mood and general behaviour, as described by parents. Since this can only be considered as anecdotal evidence, further well-controlled studies are warranted.

Another probiotic trial in autistic children was recently conducted by Kałużna-Czaplińska \& Błaszczyk ${ }^{(149)}$. Probiotic supplementation with $L$. acidophilus over 2 months led to a significant decrease in D-arabinitol and to a significant improvement in the ability to concentrate and carry out orders. D-Arabinitol is a metabolite of most pathogenic Candida species and its excretion in urine is elevated in autistic patients ${ }^{(149)}$. Candida infections have been associated with autism previously ${ }^{(35)}$. In a trial regarding the oral supplementation of vancomycin, followed by supplementation of a probiotic mixture of L. acidophilus, L. bulgaricus and Bifidobacterium bifidum $\left(40 \times 10^{9}\right.$ colony-forming units $/ \mathrm{ml}$ ), positive results were found in communication and behaviour ${ }^{(150)}$. However, the effects were attributed to vancomycin, the subject of study, and no attention was given to the possible contribution of the probiotic mixture.

Unfortunately, these studies were not of sufficient methodological quality due to the absence of control groups, multiple treatments at once and/or small sample sizes, as shown in an overview in Table 2.

Prebiotics are non-digestible food ingredients that have a beneficial effect through their selective metabolism in the intestinal tract. A reason for a potential influence of prebiotics on the treatment of symptomatology of autism concerns especially the selective stimulation of growth of lactobacilli and bifidobacteria and the production of SCFA that have an influence on gut energy metabolism, gut barrier function, water fluxes and motility ${ }^{(151)}$. However, no systematic studies have been conducted so far.

\section{Vitamin supplementation}

Autistic children often experience significant eating difficulties, specific food selectivity ${ }^{(91,152,153)}$, poor digestion $^{(94)}$, inflammatory conditions in the gut ${ }^{(154,155)}$ and reduced levels of vitamin-producing microbiota in the intestines $^{(65,156)}$. These factors could lead to a poor nutritional status ${ }^{(157)}$. A survey among physicians showed that multivitamin supplements are among the most widely recommended medical interventions for autism, and are recommended for children with autism by almost half of the interviewed physicians ${ }^{(158)}$. As such, a plethora of research has been published in respect of which vitamins, combined with a range of minerals, have been supplemented with various outcomes.

The available studies involving vitamin/mineral supplementation of autistic individuals generally lead to slightly promising results. Nutritional high-dose supplementation with ascorbic acid resulted in a statistically significant reduction in autism severity ${ }^{(159)}$. There have been many double-blind, placebo-controlled studies of very high doses of vitamin $\mathrm{B}_{6}$ with $\mathrm{Mg}$, and all but one showed positive behavioural improvements ${ }^{(25)}$. However, the studies were limited by lack of sufficient methodological quality due to small sample size and the use of assessment tools of limited validity ${ }^{(25)}$.

Two small pilot studies involving multivitamin/mineral supplementation, although of limited quality, showed positive preliminary results ${ }^{(159,160)}$. Recently, 141 children and adults with autism enrolled in a randomised, doubleblind, placebo-controlled vitamin/mineral supplementation study $^{(23)}$. The autistic subjects improved in levels of vitamins, minerals, and biomarkers of sulfation (higher levels of free and total sulfate), methylation (higher levels of $S$-adenosylmethionine and lower levels of uridine), glutathione (higher levels of reduced glutathione) and oxidative stress (higher reduced:oxidised glutathione ratio and lower levels of nitrotyrosine), compared with a control group. Significant improvements were also noted in behavioural problems, including hyperactivity, tantrumming (display of disruption, non-compliance, instigation and/or interruption frequently accompanied by aggression ${ }^{(161)}$ ) and receptive language. In addition, plasma and whole- blood levels of several vitamins and minerals, plasma levels of ATP and coenzyme Q10, and erythrocyte levels of NADH and NADPH increased from below normal to normal levels after supplementation $^{(23)}$. The combined effects of vitamin $\mathrm{B}_{6}$ and $\mathrm{Mg}$ were systematically reviewed ${ }^{(162)}$, and it was concluded that the data were insufficient to use such supplementation as a treatment for ASD. 


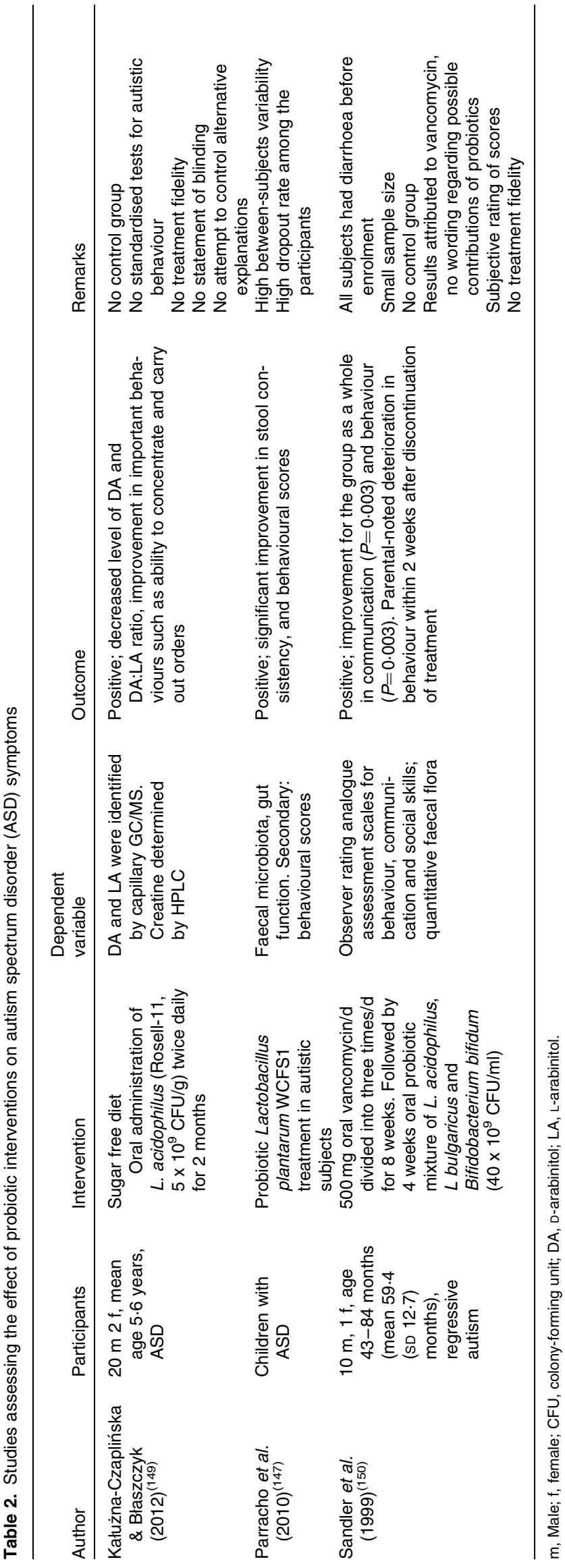

\section{Summarising considerations}

In conclusion, the exact possible biological causes and symptomatology of the autistic spectrum are still poorly understood. A tremendous amount of theories and hypotheses exist regarding this subject, even when only looking at metabolic aspects. It might well be that not all possible circulating hypotheses are described in the present paper. It can at least be stated firmly that there is considerable evidence that the gut-brain axis is involved in the aetiology of autism.

There is convincing evidence that a genetic predisposition, strengthened by early exposure to environmental agents in a vulnerable period, provides an unstable base allowing a possible development of autism. Factors such as nutrition, infections and the use of antibiotics might trigger this base and lead to the development of autism. However, there are many possible mechanisms, not all completely understood, by which this is possible and many contradicting results from an extensive amount of studies make it even harder for parents and children to find sufficient help in dealing with this disease. There is need for further research to improve diagnosing and treatment for different subsets of autism. Maybe not the severity of symptoms are diagnostic criteria for the different groups (classic autism, Asperger's syndrome, regressive autism, etc.), but the origin of symptoms (GI problems, presence of vitamin deficiencies, brain abnormalities, etc.) will determine the classification in the next Diagnostic and Statistical Manual of Mental Disorders (DSM), which would aid in finding the right treatment for the right individual.

Data supporting the presence of GI problems in ASD patients are convincing, at least for some kind of subset of children who experience a worsening of autistic symptoms along with GI symptoms. Furthermore, the increased incidence of autism might be related to exposure to Clostridium spores in the environment. In addition, cases of increased intestinal permeability were observed, although the evidence so far has been inconclusive. Multiple findings indicating metabolic abnormalities suggest that these are present in ASD patients, and that these abnormalities may partially cause the observed change in amino acid levels and levels of inflammation in these patients. Abnormalities in carbohydrate digestion and absorption could possibly explain some of the GI distress observed in a subset of ASD patients, although their role in the neurological and behavioural problems remains uncertain. Thus, a subset of ASD patients displays measurable changes in GI symptoms, composition of gut microbiota, excretion of metabolites, intestinal permeability and metabolism of several compounds. Feeding selectivity problems frequently detected in ASD patients can be a major cause of these abnormalities, and should certainly be taken into account when investigating other causes. However, this does not change the importance of investigating the effect of these abnormalities on autistic symptoms, and methods to alleviate both GI and autistic symptoms. 
Moreover, we feel that additional trials involving glutenfree diets and casein-free diets should be conducted. Current research on the hypothesised relationship between an improved gut health and a reduction of symptoms in some patients is mostly lacking sufficient methodological quality. The few trials involving pre- and probiotic, and multivitamin supplementation have been conducted with contradictive but partly promising results in reducing symptomatology. Results from these trials show the importance of conducting further research in this area. It is clear, however, that children with autism need personal support and advice, because every child experiences slightly different symptoms.

Although there is substantial evidence that the GI tract and the gut-brain axis have a central role in autism, further studies are required to understand the aetiology and the mechanisms by which these factors act, and to understand the possible cause-effect relationship between food choice and autism.

\section{Acknowledgements}

This research received no specific grant from any funding agency in the public, commercial or not-for-profit sectors.

Both M. v. d. S. and F. B. initiated the literature search. M. v. d. S. and F. B. conducted the literature research and analysed the data; M. v. d. S., V. v. B. and F. B. wrote the paper, V. v. B. was responsible for final editing while M. v. d. S. was primarily responsible for final content. All authors read and approved the final manuscript.

The authors declare no conflicts of interest and had no interaction with the food and beverage industry with respect to the contents of this article.

\section{References}

1. Willemsen-Swinkels SH \& Buitelaar JK (2002) The autistic spectrum: subgroups, boundaries and treatment. Psychiatr Clin North Am 25, 811-836.

2. Filipek PA, Accardo PJ, Baranek GT, et al. (1999) The screening and diagnosis of autistic spectrum disorders. J Autism Dev Disord 29, 439-484.

3. Newschaffer CJ, Croen LA, Daniels J, et al. (2007) The epidemiology of autism spectrum disorders. Annu Rev Public Health 28, 235-258.

4. Kogan D, Blumberg S, Schieve L, et al. (2007) Prevalence of parent-reported diagnosis of autism spectrum disorder among children in the US. Pediatrics 124, 1395-1403.

5. Duchan E \& Patel DR (2012) Epidemiology of autism spectrum disorders. Pediatr Clin North Am 59, 27-43.

6. Rutter M (2005) Incidence of autism spectrum disorders: changes over time and their meaning. Acta Paediatr $\mathbf{9 4}$ $2-15$.

7. Chess S, Korn S \& Fernandez P (1971) Psychiatric Disorders of Children with Congenital Rubella. New York: Brunner-Mazel.

8. Stromland K, Nordin V, Miller M, et al. (1994) Autism in thalidomide embryopathy: a population study. Dev Med Child Neurol 36, 351-356.
9. Hultman C, Sparen P \& Cnattingius S (2002) Perinatal risk factors for infantile autism. Epidemiology 13, 417-423.

10. Belmonte MK, Allen G, Beckel-Mitchener A, et al. (2004) Autism and abnormal development of brain connectivity. J Neurosci 24, 9228-9231.

11. Courchesne E, Pierce K, Schumann CM, et al. (2007) Mapping early brain development in autism. Neuron $\mathbf{5 6}$, 399-413.

12. ML Bauman and TL Kemper, (editors) (2006) The Neurobiology of Autism, Baltimore: Johns Hopkins University Press.

13. Bauman M \& Kemper TL (1985) Histoanatomic observations of the brain in early infantile autism. Neurology 35 , 866-867.

14. Rutter M (2000) Genetic studies of autism: from the 1970's to the millennium. J Abnorm Child Psychol 28, 3-14.

15. Sutcliffe JS (2008) Genetics: insights into the pathogenesis of autism. Science 321, 208-209.

16. Bailey A, Le Couteur A, Gottesman I, et al. (1995) Autism as a strongly genetic disorder: evidence from a British twin study. Psychol Med 25, 63-77.

17. Yap IKS, Li JV, Saric J, et al. (2008) Metabonomic and microbiological analysis of the dynamic effect of vancomycin-induced gut microbiota modification in the mouse. J Proteome Res 7, 3718-3728.

18. Gerlach EK (2003) Autism Treatment Guide. Arlington: Future Horizons.

19. Whiteley P, Rodgers J, Savery D, et al. (1999) A gluten-free diet as an intervantion for autism and associated spectrum disorders: preliminary findings. Autism 3, 45-65.

20. Whiteley P \& Shattock P (2002) Biochemical aspects in autism spectrum disorders: updating the opioid-excess theory and presenting new opportunities for biomedical intervention. Expert Opin Ther Targets 6, 175-183.

21. Millward C, Ferriter M, Calver S, et al. (2008) Gluten- and casein-free diets for autistic spectrum disorder. The Cochrane Database of Systematic Reviews 2008, issue 2, CD003498. http://www.mrw.interscience.wiley.com/cochrane/ clsysrev/articles/CD003498/frame.html

22. Parracho HM, Bingham MO, Gibson GR, et al. (2005) Differences between the gut microflora of children with autistic spectrum disorders and that of healthy children. J Med Microbiol 54, 987-991.

23. Adams JB, Audhya T, McDonough-Means S, et al. (2011) Effect of a vitamin/mineral supplement on children and adults with autism. BMC Pediatrics 11, 111.

24. Adams JB \& Holloway C (2004) Pilot study of a moderate dose multivitamin/mineral supplement for children with autistic spectrum disorder. J Altern Complement Med 10, 1033-1039.

25. Adams JB, George F \& Audhya T (2006) Abnormally high plasma levels of vitamin $\mathrm{B}_{6}$ in children with autism not taking supplements compared to controls not taking supplements. J Altern Complement Med 12, 59-63.

26. Song YL, Liu CX \& Finegold SM (2004) Real-time PCR quantitation of clostridia in feces of autistic children. Appl Environ Microbiol 70, 6459-6465.

27. Horvath K, Papadimitriou JC, Rabsztyn A, et al. (1999) Gastrointestinal abnormalities in children with autistic disorder. J Pediatr 135, 559-563.

28. de Magistris L, Familiari V, Pascotto A, et al. (2010) Alterations of the intestinal barrier in patients with autism spectrum disorders and in their first-degree relatives. J Pediatr Gastroenterol Nutr 51, 418-424.

29. Adams JB, Johansen LJ, Powell LD, et al. (2011) Gastrointestinal flora and gastrointestinal status in children with autism - comparisons to typical children and correlation with autism severity. BMC Gastroenterol 11, 22. 
30. Finegold SM (2008) Therapy and epidemiology of autism clostridial spores as key elements. Med Hypotheses 70, 508-511.

31. Finegold SM, Dowd SE, Gontcharova V, et al. (2010) Pyrosequencing study of fecal microflora of autistic and control children. Anaerobe 16, 444-453.

32. Finegold SM, Molitoris DR, Song Y, et al. (2002) Gastrointestinal microflora studies in late-onset autism. Clin Infect Dis 35, 6-16.

33. Black C, Kaye JA \& Jick H (2002) Relation of childhood gastrointestinal disorders to autism: nested case-control study using data from the UK General Practice Research Database. BMJ 325, 419-421.

34. Ibrahim SH, Voigt RG, Katusic SK, et al. (2009) Incidence of gastrointestinal symptoms in children with autism: a population-based study. Pediatrics 124, 680-686.

35. Shaw W, Kassen E \& Chaves E (2000) Assessment of antifungal drug therapy in autism by measurement of suspected microbial metabolites in urine with gas chromatographymass spectrometry. Clin Pract Alternat Med 1, 15-26.

36. White JF (2003) Intestinal pathophysiology in autism. Exp Biol Med 228, 639-649.

37. Valenci-McDermott M, McVicar K, Rapin I, et al. (2006) Frequency of gastrointestinal symptoms in children with autistic spectrum disorders and association with family history of autoimmune disease. J Dev Behav Pediatr 27, 128-136.

38. Goodwin MS, Goodwin TC \& Cowen MA (1971) Malabsorption and cerebral dysfunction: a multivariate and comparative study of autistic children. J Autism Dev Disord 1, 48-62.

39. Sun ZJ \& Cade JR (1999) A peptide found in schizophrenia and autism causes behavioral changes in rats. Autism 3, $85-95$.

40. Sun ZJ, Cade R, Fregly MJ, et al. (1999) $\beta$-Casomorphin induces Fos-like immunoreactivity in discrete brain regions relevant to schizophrenia and autism. Autism 3, 67-93.

41. D'Eufemia P, Celli M, Finocchiaro R, et al. (1996) Abnormal intestinal permeability in children with autism. Acta Paediatr 85, 1076-1079.

42. Kerwin ME, Eicher PS \& Gelsinger J (2005) Parental report of eating problems and gastrointestinal symptoms in children with pervasive developmental disorders. Child Health Care 34, 217-234.

43. Wakefield AJ, Murch SH, Anthony A, et al. (1998) Ileallymphoid-nodular hyperplasia, non-specific colitis, and pervasive developmental disorders. Am J Gastroenterol 35, 637-641.

44. Wakefield AJ, Ashwood P, Limb K, et al. (2005) The significance of ileo-colonic lymphoid nodular hyperplasia in children with autistic spectrum disorder. Eur J Gastroenterol Hepatol 17, 827-836.

45. Bolte ER (1998) Autism and Clostridium tetani. Med Hypotheses 51, 133-144.

46. Konstantareas MM \& Homatidis S (1987) Brief report: ear infections in autistic and normal children. $J$ Autism Dev Disord 17, 585-594.

47. Gordon A (1989) Ear disorders in autistic children. J Autism Dev Disord 19, 470-473.

48. Niehus R \& Lord C (2006) Early medical history of children with autism spectrum disorders. J Dev Behav Pediatr 27, S120-S127.

49. George WL, Volpicelli NA, Stiner DB, et al. (1979) Relapses of pseudomembranous colitis after vancomycin therapy. $N$ Engl J Med 301, 414-415.

50. Portnoy D, Soneji A, Murray D, et al. (1981) Pseudomembranous colitis: multiple relapses after treatment with metronidazole. Can Med Assoc J 124, 1603-1605.

51. Pultz NJ, Stiefel U \& Donskey CJ (2005) Effects of daptomycin, linezolid, and vancomycin on establishment of intestinal colonization with vancomycin-resistant enterococci and extended-spectrum- $\beta$-lactamase-producing Klebsiella pneumonae in mice. Antimicrob Agents Chemother 49, 3513-3516.

52. Martirosian G, Ekiel A, Aptekorz M, et al. (2011) Fecal lactoferrin and Clostridium spp. in stools of autistic children. Anaerobe 17, 43-45.

53. Cao X, Lin P, Jiang $\mathrm{P}$, et al. (2013) Characteristics of the gastrointestinal microbiome in children with autism spectrum disorder: a systematic review. Shanghai Arch Psych 25, 342-353.

54. Anderson RJ, Bendell DJ, Garnett I, et al. (2002) Identification of indolyl-3-acryloylglycine in the urine of people with autism. J Pharm Pharmacol 54, 295-298.

55. Bull G, Shattock P, Whiteley P, et al. (2003) Indolyl-3acryloylglycine (IAG) is a putative diagnostic urinary marker for autism spectrum disorders. Med Sci Monit $\mathbf{9}$, 422-425.

56. Shattock P, Kennedy A, Rowell F, et al. (1990) Role of neuropeptides in autism and their relationships with classical neurotransmitters. Brain Dysfunct 3, 328-345.

57. Moore JG, Jessop LD \& Osborne DN (1987) Gaschromatographic and mass-spectrometric analysis of the odor of human feces. Gastroenterology 93, 1321-1329.

58. Marklová E (1999) Where does indolylacrylic acid come from? Amino Acids 17, 401-413.

59. Shattock P, Whiteley P \& Savery D (2000) Autism as a Metabolic Disorder and Guidelines for Dietary Intervention. Sunderland: Autism Research Unit, University of Sunderland.

60. Shattock P \& Whiteley P (2006) The role of tryptophan in autism and related disorders. The Nutrition Practitioner. http://www.espa-research.org.uk/linked/iagandtryptophan. pdf

61. Bell JG, Sargent JR, Tocher DR, et al. (2000) Red blood cell fatty acid composition in a patient with autistic spectrum disorder: a characteristic abnormality in neurodevelopmental disorders. Prostaglandins Leukot Essent Fatty Acids $\mathbf{6 3}$, $21-25$.

62. Secondulfo M, De Magistris L, Fiandra R, et al. (2001) Intestinal permeability in Crohn's disease patients and their first degree relatives. Dig Liver Dis 33, 680-685.

63. Munkholm P, Langholz E, Hollander D, et al. (1994) Intestinal permeability in patients with Crohn's disease and ulcerative colitis and their first degree relatives. Gut $\mathbf{3 5}$ $68-72$.

64. Watts T, Berti I, Sapone A, et al. (2005) Role of the intestinal tight junction modulator zonulin in the pathogenesis of type I diabetes in BB diabetic prone rats. Proc Natl Acad Sci U S A 102, 2016-2021.

65. Wang LV, Christophersen CT, Sorich MJ, et al. (2011) Low relative abundances of the mucolytic bacterium Akkermansia muciniphila and Bifidobacterium spp. in feces of children with autism. Appl Environ Microbiol 77, 6718-6721.

66. Kleerebezem M \& Vaughan EE (2009) Probiotic and gut lactobacilli and bifidobacteria: molecular approaches to study diversity and activity. Annu Rev Microbiol 63, 269-290.

67. Robertson MA, Sigalet DL, Holst JJ, et al. (2008) Intestinal permeability and glucagon-like peptide- 2 in children with autism: a controlled pilot study. J Autism Dev Disord 38, 1066-1071.

68. Drucker DJ (2005) Biologic actions and therapeutic potential of the proglucagon-derived peptides. Nat Clin Pract Endocrinol Metab 1, 22-31.

69. Sigalet D, Bawazir O, Martin G, et al. (2006) Glucagon-like peptide-2 induces a specific pattern of adaptation in remnant jejunum. Dig Dis Sci 51, 1557-1566. 
70. James SJ, Cutler P, Melnyk S, et al. (2004) Metabolic biomarkers of increased oxidative stress and impaired methylation capacity in children with autism. Am J Clin Nutr 80, 1611-1617.

71. James SJ, Melnyk S, Fuchs G, et al. (2009) Efficacy of methylcobalamin and folinic acid treatment on glutathione redox status in children with autism. Am J Clin Nutr 89, 425-430.

72. Tirouvanziam R, Obukhanych TV, Laval J, et al. (2012) Distinct plasma profile of polar neutral amino acids, leucine, and glutamate in children with autism spectrum disorders. J Autism Dev Disord 42, 827-836.

73. Geier DA, Kern JK, Garver CR, et al. (2009) Biomarkers of environmental toxicity and susceptibility in autism. J Neurol Sci 280, 101-108.

74. Ryaskin OT (2004) Trends in Autism Research. New York: Nova Biomedical Books.

75. Yap IKS, Angley M, Veselkov KA, et al. (2010) Urinary metabolic phenotyping differentiates children with autism from their unaffected siblings and age-matched controls. J Proteome Res 9, 2996-3004.

76. Geier D, Kern J, Garver C, et al. (2009) A prospective study of transsulfuration biomarkers in autistic disorders. Neurochem Res 34, 386-393.

77. Alberti A, Pirrone P, Elia M, et al. (1999) Sulphation deficit in "low-functioning" autistic children: a pilot study. Biol Psychiatry 46, 420-424.

78. Strous RD, Golubchik P, Maayan R, et al. (2005) Lowered DHEA-S plasma levels in adult individuals with autistic disorder. Eur Neuropsychopharmacol 15, 305-309.

79. McFadden SA (1996) Phenotypic variation in xenobiotic metabolism and adverse environmental response: focus on sulfur-dependent detoxification pathways. Toxicology 111, 43-65.

80. Evans C, Dunstan RH, Rothkirch T, et al. (2008) Altered amino acid excretion in children with autism. Nutr Neurosci 11, 9-17.

81. Pangborn JB \& Baker SM (2001) Biomedical Assessment Options for Children with Autism and Related Problems. San Diego, CA: Autism Research Institute.

82. Aldred S, Moore KM, Fitzgerald M, et al. (2003) Plasma amino acid levels in children with autism and their families. J Autism Dev Disord 33, 93-97.

83. Lam KSL, Aman MG \& Arnold LE (2006) Neurochemical correlates of autistic disorder: a review of the literature. Res Dev Dis 27, 254-289.

84. Young JG, Kavanagh ME, Anderson GM, et al. (1982) Clinical neurochemistry of autism and associated disorders. J Autism Dev Disord 12, 147-165.

85. Shimmura C, Suda S, Tsuchiya KJ, et al. (2011) Alteration of plasma glutamate and glutamine levels in children with high-functioning autism. PLOS ONE 6, e25340.

86. Kojima S, Nakamura T, Nidaira T, et al. (1999) Optical detection of synaptically induced glutamate transport in hippocampal slices. J Neurosci 19, 2580-2588.

87. Ortinski PI, Dong J, Mungenast A, et al. (2010) Selective induction of astrocytic gliosis generates deficits in neuronal inhibition. Nat Neurosci 13, 584-591.

88. Pais T, Figueiredo C, Peixoto R, et al. (2008) Necrotic neurons enhance microglial neurotoxicity through induction of glutaminase by a MyD88-dependent pathway. J Neuroinflamm 5, 43.

89. Laurence J \& Fatemi S (2005) Glial fibrillary acidic protein is elevated in superior frontal, parietal and cerebellar cortices of autistic subjects. Cerebellum 4, 206-210.

90. Bandini LG, Anderson SE, Curtin C, et al. (2010) Food selectivity in children with autism spectrum disorders and typically developing children. J Pediatr 157, 259-264.
91. Arnold GL, Hyman SL, Mooney RA, et al. (2003) Plasma amino acids profiles in children with autism: potential risk of nutritional deficiencies. J Autism Dev Disord 33, 449-454.

92. Jacobs DM, Gaudier E, Duynhoven Jv, et al. (2009) Nondigestible food ingredients, colonic microbiota and the impact on gut health and immunity: a role for metabolomics. Curr Drug Metab 10, 41-54.

93. Wong JMW \& Jenkins DJA (2007) Carbohydrate digestibility and metabolic effects. J Nutr 137, 2539S-2546S

94. Williams BL, Hornig M, Buie T, et al. (2011) Impaired carbohydrate digestion and transport and mucosal dysbiosis in the intestines of children with autism and gastrointestinal disturbances. PLOS ONE 6, e24585.

95. Mowat A (2003) Anatomical basis of tolerance and immunity to intestinal antigens. Nat Rev Immunol 3, 331-341.

96. Ashwood P, Anthony A, Pellicer AA, et al. (2003) Intestinal lymphocyte populations in children with regressive autism: evidence for extensive mucosal immunopathology. J Clin Immunol 23, 504-517.

97. Ashwood P \& Wakefield AJ (2006) Immune activation of peripheral blood and mucosal $\mathrm{CD}^{+}$lymphocyte cytokine profiles in children with autism and gastrointestinal symptoms. J Neuroimmunol 173, 126-134.

98. Ashwood P, Krakowiak P, Hertz-Picciotto I, et al. (2011) Elevated plasma cytokines in autism spectrum disorders provide evidence of immune dysfunction and are associated with impaired behavioral outcome. Brain Behav Immun 25, 40-45.

99. DeFelice ML, Ruchelli ED, Markowitz JE, et al. (2003) Intestinal cytokines in children with pervasive developmental disorders. Am J Gastroenterol 98, 1777-1782.

100. Fernell E, Fagerberg UL \& Hellström PM (2007) No evidence for a clear link between active intestinal inflammation and autism based on analyses of faecal calprotectin and rectal nitric oxide. Acta Paediatr 96, 1076-1079.

101. Eigenmann PA (2002) $\mathrm{T}$ lymphocytes in food allergy: overview of an intricate network of circulating and organresident cells. Pediatr Allergy Immunol 13, 162-171.

102. Gurney JG, McPheeters ML \& Davis MM (2006) Parental report of health conditions and health care use among children with and without autism: National Survey of Children's Health. Arch Pediatr Adolesc Med 160, 825-830.

103. Lucarelli S, Frediani T, Zingoni AM, et al. (1995) Food allergy and infantile autism. Panminerva Med 37, 137-141.

104. Sabra A, Bellanti JA, Hartmann D, et al. (2012) Gastrointestinal and behavioral dysfunction in children with non-IgEmediated food allergy, ileal-nodular-lymphoid hyperplasia (ILNH) and low Th1 function: a new clinical-immunologic constellation. J Food Allergy 1, 36-43.

105. Jyonouchi H (2009) Food allergy and autism spectrum disorders: is there a link? Curr Allergy Asthma Rep 9, 194-201.

106. Jyonouchi H, Geng L, Ruby A, et al. (2005) Evaluation of an association between gastrointestinal symptoms and cytokine production against common dietary proteins in children with autism spectrum disorders. J Pediatr 146, 605-610.

107. Hwang J-B, Sohn SM \& Kim AS (2009) Prospective followup oral food challenge in food protein-induced enterocolitis syndrome. Arch Dis Child 94, 425-428.

108. LeBreton M (2001) Dietary Intervention and Autism: Implementing the Gluten Free and Casein Free Diet for Autistic Children and Adults: A Practical Guide for Parents. London: Jessica Kingsley.

109. Levy SE, Mandell DS, Merhar SBA, et al. (2003) Use of complementary and alternative medicine among children recently diagnosed with autistic spectrum disorder. $J$ Dev Behav Pediatr 24, 418-423. 
110. Bird BL, Russo DC \& Cataldo MF (1977) Considerations in the analysis and treatment of dietary effects on behavior: a case study. J Autism Child Schizophr 7, 373-382.

111. Patel K \& Curtis LT (2007) A comprehensive approach to treating autism and attention-deficit hyperactivity disorder: a prepilot study. J Altern Complement Med 13, 1091-1097.

112. Cade JR, Privette RM, Fregly MJ, et al. (2000) Autism and schizophrenia: intestinal disorders. Nutr Neurosci 3, 57-72.

113. Elder JH, Shanker M, Shuster J, et al. (2006) The gluten-free, casein-free diet in autism: results of a preliminary double blind clinical trial. J Autism Dev Disord 36, 413-420.

114. Irvin DS (2006) Using analog assessment procedures for determining the effects of a gluten-free and casein-free diet on rate of problem behaviors for an adolescent with autism. Behav Intervent 21, 281-286.

115. Knivsberg AM, Reichelt KL, Hoien T, et al. (2002) A randomized, controlled study of dietary intervention in autistic syndromes. Nutr Neurosci 5, 251-261.

116. Knivsberg A, Reichelt KL \& Hoien T (2003) Effect of a dietary intervention on autistic behavior. Focus Autism Other Dev Disabil 18, 248-257.

117. Shanahan MR, Venturini AJ, Daiss JL, et al. (2000) Peptide diagnostic markers for human disorders. Patent application, EP 0969015 A3.

118. Reichelt KL, Knivsberg A, Lind G, et al. (1991) Probable etiology and possible treatment of childhood autism. Brain Dysfunct 4, 308-319.

119. Mulloy A, Lang L, O'Reilly M, et al. (2010) Gluten-free and casein-free diets in the treatment of autism spectrum disorders: a systematic review. Res Autism Spect Disord 4, 328-339.

120. Christison GW \& Ivany K (2006) Elimination diets in autism spectrum disorders: any wheat amidst the chaff? J Dev Behav Pediatr 27, S162-S171.

121. Wright B, Brzozowski AM, Calvert E, et al. (2005) Is the presence of urinary indolyl-3-acryloylglycine associated with autism spectrum disorder? Dev Med Child Neurol 47, 190-192.

122. Mantos A, Ha E, Caine-Bish N, et al. (2011) Effects of the gluten-free/casein-free diet on the nutritional status of children with autism. J Am Diet Assoc 111, A32.

123. Teschemacher H (2003) Opioid receptor ligands derived from food proteins. Curr Pharm Des 9, 1331-1344.

124. Panksepp J (1979) A neurochemical theory of autism. Trends Neurosci 2, 174-177.

125. Reichelt KL, Hole K, Hamberger A, et al. (1981) Biologically active peptide-containing fractions in schizophrenia and childhood autism. Adv Biochem Psychopharmacol 28, 627-643

126. Brantl V, Teschemacher H, Bläsig J, et al. (1981) Opioid activities of $\beta$-casomorphins. Life Sci 28, 1903-1909.

127. Nelson KB, Grether JK, Croen LA, et al. (2001) Neuropeptides and neurotrophins in neonatal blood of children with autism or mental retardation. Ann Neurol 49, 597-606.

128. Teeling JL \& Perry VH (2009) Systemic infection and inflammation in acute CNS injury and chronic neurodegeneration: underlying mechanisms. Neuroscience 158, 1062-1073.

129. Kaminski S, Cieslinska A \& Kostyra E (2007) Polymorphism of bovine $\beta$-casein and its potential effect on human health. J Appl Genet 48, 189-198.

130. Kreil G, Umbach M, Brantl V, et al. (1983) Study on the enzymatic degradation of $\beta$-casomorphin. Life Sci 33, $137-140$.

131. Lambeir A, Durinx C, Scharpé S, et al. (2003) Dipeptidylpeptidase IV from bench to bedside: an update on structural properties, functions, and clinical aspects of the enzyme DPP IV. Crit Rev Clin Lab Sci 40, 209-294.

132. Kost NV, Sokolov OY, Kurasova OB, et al. (2009) $\beta$-Casomorphins-7 in infants on different type of feeding and different levels of psychomotor development. Peptides $\mathbf{3 0}$, $1854-1860$.

133. Hunter LC, O'Hare A, Herron WJ, et al. (2003) Opioid peptides and dipeptidyl peptidase in autism. Dev Med Child Neurol 45, 121-128.

134. Longstreth GF, Thompson WG, Chey WD, et al. (2006) Functional bowel disorders. Gastroenterology 130, $1480-1491$

135. Bingham M (2003) Functional foods: dietary intervention strategies in autistic spectrum disorders. In Food Science and Technology Bulletin ${ }^{T M}$ : Functional Foods, vol. 1, pp. 4-1-4-11 [M Bingham, editor]. Reading: IFIS Publishing.

136. Food and Agriculture Organization\& World Health Organization (2001) Health and Nutritional Properties of Probiotics in Food Including Powder Milk with Live Lactic Acid Bacteria. Report of a Joint FAO/WHO Expert Consultation. Geneva: WHO.

137. Marteau P, Flourie B, Pochart P, et al. (1990) Role of the microbial lactase (EC $3 \cdot 2 \cdot 1 \cdot 23$ ) activity from yoghurt on the intestinal absorption of lactose: an in vivo study in lactase-deficient humans. Br J Nutr 64, 71-79.

138. Sanders ME (1993) Summary of the conclusions from a consensus panel of experts on health attributes on lactic cultures: significance to fluid milk products containing cultures. J Dairy Sci 76, 1819-1828.

139. Oksanen PJ, Salminen S, Saxelin M, et al. (1990) Prevention of travellers diarrhoea by Lactobacillus GG. Ann Med 22, 53-56.

140. Saavedra JM, Bauman NA, Oung I, et al. (1994) Feeding of Bifidobacterium bifidum and Streptococcus thermophilus to infants in hospital for prevention of diarrhoea and shedding of rotavirus. Lancet 344, 1046-1049.

141. Guslandi M, Mezzi G, Sorghi M, et al. (2000) Saccharomyces boulardii in maintenance treatment of Crohn's disease. Dig Dis Sci 45, 1462-1464.

142. Rembacken BJ, Snelling AM, Hawkey PM, et al. (1999) Non-pathogenic Escherichia coli versus mesalizine for the treatment of ulcerative colitis: a randomised trial. Lancet 354, 635-639.

143. Burns AJ \& Rowland IR (2000) Anti-carcinogenicity of probiotics and prebiotics. Curr Issues Intest Microbiol 1, $13-24$.

144. Marteau P, Minekus M, Havenaar R, et al. (1997) Survival of lactic acid bacteria in a dynamic model of the stomach and small intestine: validation and the effects of bile. J Dairy $S c i$ 80, 1031-1037.

145. Arunachalam K, Gill HS \& Chandra RK (2000) Enhancement of natural immune function by dietary consumption of Bifidobacterium lactis (HN019). Eur J Clin Nutr 54, 263-267.

146. Isolauri E, Sütas Y, Kankaanpää P, et al. (2001) Probiotics: effects on immunity. Am J Clin Nutr 73, 444s-450s.

147. Parracho HMRT, Gibson GR, Knott F, et al. (2010) A doubleblind, placebo-controlled, crossover-designed probiotic feeding study in children diagnosed with autistic spectrum disorders. Int J Probiot Prebiot 5, 69-74.

148. Thomson H (2006) Really friendly bacteria. New Scientist. http://www.newscientist.com/blog/shortsharpscience/2006/ 09/really-friendly-bacteria.html

149. Kałużna-Czaplińska J \& Błaszczyk S (2012) The level of arabinitol in autistic children after probiotic therapy. Nutrition 28, 124-126.

150. Sandler RH, Finegold SM, Bolte ER, et al. (2000) Short-term benefit from oral vancomycin treatment of regressive-onset autism. J Child Neurol 15, 429-435.

151. Gibson GR \& Roberfroid MB (1995) Dietary modulation of the human colonic microbiota: introducing the concept of prebiotics. J Nutr 125, 1401-1412. 
152. Williams PG, Dalrymple N \& Neal J (2000) Eating habits of children with autism. Pediatr Nurs 26, 259-264.

153. Herndon AC, DiGuiseppi C, Johnson SL, et al. (2009) Does nutritional intake differ between children with autism spectrum disorders and children with typical development? J Autism Dev Disord 29, 212-222.

154. Jyonouchi H, Sun S \& Le H (2001) Proinflammatory and regulatory cytokine production associated with innate and adaptive immune responses in children with autism spectrum disorders and developmental regression. J Neuroimmunol 120, 170-179.

155. Bauer S, Kerr BJ \& Patterson PH (2007) The neuropoietic cytokine family in development, plasticity, disease and injury. Nat Rev Neurosci 8, 221-232.

156. Guarner F \& Malagelada J-R (2003) Gut flora in health and disease. Lancet 361, 512-519.

157. Kidd PM (2002) Autism, an extreme challenge to integrative medicine. Part 1: the knowledge base. Alt Med Rev 7, 292-316.

158. Golnik A \& Ireland M (2009) Complementary alternative medicine for children with autism: a physician survey. J Autism Dev Disord 39, 996-1005.

159. Dolske MC, Spollen J, McKay S, et al. (1993) A preliminary trial of ascorbic acid as supplemental therapy for autism. Prog Neuropsychopharmacol Biol Psychiatry 17, 765-774.

160. Kaplan BJ, Fisher JE, Crawford SG, et al. (2004) Improved mood and behavior during treatment with a mineralvitamin supplement: an open-label case series of children. J Child Adolesc Psychopharmacol 14, 115-122.

161. Duda D \& Heindel A (2004) Positive behavior support. Defining \& selecting target behaviors. Florida: College of Education, University of South Florida. http://myweb.usf. edu/ aheindel/PBSsection3b.html (accessed July 2012).
162. Nye C \& Brice A (2005) Combined vitamin $B_{6}$-magnesium treatment in autism spectrum disorder. The Cochrane Database of Systematic Reviews 2005, 4, CD003497. http:// www.mrw.interscience.wiley.com/cochrane/clsysrev/articles/ CD003497/frame.html

163. Adams L \& Conn S (1997) Nutrition and its relationship to autism. Focus Autism Other Dev Disabil 12, 53-58.

164. Harris C \& Card B (2012) A pilot study to evaluate nutritional influences on gastrointestinal symptoms and behavior patterns in children with autism spectrum disorder. Complement Ther Med 20, 437-440.

165. Herbert MR \& Buckley JA (2013) Autism and dietary therapy case report and review of the literature. J Child Neurol $\mathbf{2 8}$, 975-982.

166. Knivsberg A-M, Wiig K, Lind G, et al. (1990) Dietary intervention in autistic syndromes. Brain Dysfunct 3, 315-327.

167. Knivsberg AM, Reichelt KL, Nødland M, et al. (1995) Autistic syndromes and diet: a follow-up study. Scand J Educ Res 39, 223-236.

168. O'Banion D, Armstrong B, Cummings R, et al. (1978) Disruptive behavior: a dietary approach. J Autism Child Schizophr 8, 325-337.

169. Reichelt K, Ekrem J \& Scott H (1990) Gluten, milk proteins and autism: dietary intervention effects on behavior and peptide secretion. J Appl Nutr 42, 1-10.

170. Seung H, Rogalski Y, Shankar M, et al. (2007) The glutenand casein-free diet and autism: communication outcomes from a preliminary double-blind clinical trial. $J$ Med Speech Lang Pathol 15, 337-345.

171. Whiteley P, Haracopos D, Knivsberg AM, et al. (2010) The ScanBrit randomised, controlled, single-blind study of a gluten- and casein-free dietary intervention for children with autism spectrum disorders. Nutr Neurosci 13, 87-100. 